possibly three of them before the age of $36 .{ }^{18}$ Thus there is substantial credibility for this hypothesis.

If a causal interpretation of the association is accepted, can the risks be minimised without abandoning HRT ? Some workers have suggested that this could be done by prescribing oestrogens sequentially with progestogens to induce regular endometrial shedding. ${ }^{19}$ Nevertheless, we have little hard information on which to judge this claim. Cohen and Deppe ${ }^{20}$ have recently reported six patients who took sequential agents for oral contraception and subsequently developed endometrial carcinoma. None was obese or diabetic, but one was nulliparous and two were hypertensive. Other workers have also reported such tumours in long-term users of sequential oral contraceptives, ${ }^{2122}$ suggesting that as administered synthetic progestogens were not totally protective.

Thus the circumstantial evidence that HRT is associated with endometrial cancer is now so strong and comes from so many studies that it cannot be ignored. A causal interpretation of the association seems likely on the basis of the strength and magnitude of the relative risk, the absence or control of obvious confounding factors (such as age, diabetes, hypertension, obesity, and parity), the increased incidence of the tumour in association with increased use of this treatment, and the intrinsic credibility of the hypothesis.

${ }^{1}$ Mulley, G, and Mitchell, J R A, Lancet, 1976, 1, 1397.

2 Lindsay, R, et al, Lancet, 1976, 1, 1038.

${ }^{3}$ Smith, D C, et al, New England fournal of Medicine, 1975, 293, 1164.

4 Ziel, H K, and Finkle, W D, New England fournal of Medicine, 1975, 293, 1167.

${ }^{5}$ Mack, T M, et al, New England fournal of Medicine, 1976, 294, 1262.

6 Lancet, 1977, 1, 577.

7 Doll, R, et al, Lancet, 1977, 1, 745.

${ }^{8}$ Gray, L A, Christopherson, W M, and Hoover, R N, Obstetrics and Gynecology, 1977, 49, 385 .

9 Weiss, N S, Szekely, D R, and Austin, D F, New England Fournal of Medicine, 1976, 294, 1259.

10 Jackson, R L, and Dockerty, M B, American fournal of Obstetrics and Gynecology, 1957, 73, 161.

11 Siiteri, P K, Schwartz, B E, and MacDonald, P C, Gynecologic Oncology, $1974,2,228$.

12 MacMahol, B, Gynecologic Oncology, 1974, 2, 122

${ }_{13}$ MacDonald, P C, and Siiteri, P K, Gynecologic Oncology, 1974, 2, 259.

${ }_{14}$ Meissner, W A, Sommers, S C, and Sherman, G, Cancer, 1957, 10, 500.

15 Gusberg, S B, American fournal of Obstetrics and Gynecology, 1963, 87, 662.

16 Gusberg, S B, and Kaplan, A L, American fournal of Obstetrics and Gynecology, 1963, 87, 662 .

17 Gusberg, S B, American fournal of Obstetrics and Gynecology, 1976, 126, 535.

18 Cutler, B S, et al, New England fournal of Medicine, 1972, 287, 628.

19 Whitehead, M I, et al, cited in Lancet, 1977, 1, 577.

${ }^{20}$ Cohen, C J, and Deppe, G, Obstetrics and Gynecology, 1977, 49, 390.

21 Silverberg, S G, and Makowski, E L, Obstetrics and Gynecology, 1975, 46, 503.

${ }^{22}$ Kelly, H W, et al, Obstetrics and Gynecology, 1976, 47, 200.

\section{Need part time be second-rate?}

Part-time doctors have an unfortunate amateur image. Some of the opprobrium is a legacy of the time when a few NHS consultants spent almost every afternoon with their private patients (or on the golf course). Some comes from the conviction among dedicated enthusiasts that total commitment is needed in demanding specialties; and, finally, some comes from occasional examples of married women working part time who take a lot of time off to cope with their sick children and other real or manufactured domestic crises.

None of these objections should be allowed to justify a blanket condemnation of part-time work, and, indeed, the Royal College of Physicians of London has recently produced a report ${ }^{1}$ encouraging women to undertake part-time training in internal medicine. Reasonably enough, the report advises women (and men whose domestic commitments make parttime work attractive) to complete the preregistration year in conventional posts, but thereafter it sees no essential reason for specialists in training to work full time.

Training may be arranged on a part-time basis in two ways. Firstly, the DHSS circular $\operatorname{HM(69)6}$ gave regional hospital boards powers to establish part-time appointments in any grade from house officer to senior registrar, tailor-made to the individual. Sadly - as the report admits-when an application is made the administrative red tape may take as long as a year to untangle, and not surprisingly discouraged women doctors sometimes drift into a clinical assistantship or a sessional job in general practice. Alternatively, a full-time registrar or SHO post may be split into two five-session jobs-but again the arrangements have to be made in response to individual demand and there may be administrative delays.

Consultant appointments do not even have the backing of a Department circular for those seeking seven or fewer sessions a week. Some regions-notably Oxford-have advertised consultant posts with the comment that "doctors able to offer only seven sessions because of domestic commitments are encouraged to apply" and have appointed married women as the candidates of greatest merit. There is still, however, a suspicion in some minds that making part-time consultant appointments with so few sessions is unacceptable politically because it encourages private practice or that in some way a part-time appointment is second-best.

The remarkable aspect of these schemes is that they seem designed to cater for a tiny minority of all women doctors. In effect, the DHSS attitude seems to be that special arrangements may be made for any woman who creates a fuss and makes a personal approach to her postgraduate dean to get him to pull the right strings. Such an approach may have been appropriate when the few women who qualified as doctors were expected either to stay single or to stop work; it makes no sense when women make up $30-40 \%$ of the total student intake. Medicine-and other professions such as nursing-needs to recognise that most women want to have children and that they prefer to divide the years from 25 to 45 between their careers and their families. These practical arguments were used successfully by the BMA to persuade the EEC to recognise the importance of part-time specialist training. ${ }^{2}$

The college report is realistic in suggesting that women pursuing part-time training should generally avoid the most competitive specialties; but for most branches of medicine there should be many more opportunities for women wishing to work 5-7 sessions a week. There are at present wide variations in the interpretation of $\mathrm{HM}(69) 6$ from region to region, reflecting its permissive nature. What we need is a coherent policy for the part-time employment of a large proportion of all women doctors-but doing first-rate and not second-rate work. Such a policy should be central to any realistic projections made by the central manpower committee for the next decade.

\footnotetext{
${ }^{1}$ Royal College of Physicians of London, Part-time Postgraduate Training in Medicine. London, Royal College of Physicians, 1977, price 30p. ${ }^{2}$ British Medical fournal, 1976, 1, 1355.
} 